\title{
COLLOQUIA
}

\author{
Ljiljana Dobrovšak \\ Institute of Social Sciences Ivo Pilar \\ Zagreb \\ https://orcid.org/0000-0002-1899-2306 \\ Ljiljana.Dobrovsak@pilar.hr \\ Ivana Žebec Šilj \\ Institute of Social Sciences Ivo Pilar \\ Zagreb \\ https://orcid.org/0000-0001-5041-9537 \\ Ivana.Zebec@pilar.hr
}

\section{The Alexander Family Chronicle ${ }^{1}$}

\begin{abstract}
The paper focuses on the history of Zagreb's prominent Jewish family, the Alexanders (or Aleksanders), who were influential in the cultural, economic and social life of the city and Croatia for almost a century. At the time of their arrival in Zagreb and after the end of the First World War, they all belonged to the Jewish religious denomination; later most of them converted to Catholicism and one was an Evangelical Christian (Protestant). The Alexander family moved to Zagreb from Burgenland (Güssing) in the 1850s. Upon their arrival, they worked in commerce and were known as diligent businessmen. Soon they became respected and wealthy patrons well-known in Zagreb, Croatia and abroad. The second-generation family members were distinguished physicians, lawyers,

1 In the documents and sources, the Alexander family name appears in various forms, such as Alexander, Alexandar, Aleksander, Aleksandar; in this text, we will use the German version, Alex-

This is an Open Access article distributed under the terms of the Creative Commons Attribution 3.0 PL License (creativecommons.org/licenses/by/3.0/pl/), which permits redistribution, commercial and non-commercial, provided that the article is properly cited. ๑ The Author(s), 2020.

Publisher: Institute of Slavic Studies, Polish Academy of Sciences

Editor-in-chief: Jolanta Sujecka

Conception and academic editing of this issue: Aleksandra Twardowska, Katarzyna Taczyńska
\end{abstract} ander. 
engineers, artists, professors and businessmen. They formed marriage alliances with Zagreb's prominent Jewish and Catholic families and socialised with the nobility, thus making acquaintances and forming social networks that upgraded their social status. Also, they were cosmopolitans with one foot in Zagreb and the other in Vienna. Thereby, Budapest was not far-fetched for them. Among the most prominent and distinguished family members, one finds the brothers Aleksander/ Šandor (1866-1929) and Samuel David (1862-1943). They were well-respected industrialists, founders of Zagreb's brewery, malt factory and cement factory. They were also board members of several banks and founders of industrialists' associations. Thus, their work and diligence were much appreciated during the First World War, for which Aleksander was awarded an Austro-Hungarian noble title. The post-war unification of the Kingdom of Serbs, Croats and Slovenes had no negative impact on their social standing. Thereby, the brothers managed to continue their business successfully, and were greatly appreciated by the newly formed political elite. Later, at the beginning of the Second World War, the majority of the family members managed to escape Nazi persecution, while some perished in the Holocaust. Today, descendants of this large family live scattered around the world, in Israel, the United States, Italy and Zagreb. The only visible memory trace - proof of the family's existence in Zagreb - are the stairs in the Tuškanac city park, named after Šandor von Alexander of Sesvete.

Key words: Alexander family, Jews, entrepreneurs, Zagreb.

\section{Introduction}

Ther n every European city at a certain point in time, some Jewish families became part of the elite (cultural, social, political or economic). In Vienna, they were the Arnsteins, the coal baron Gutmann, the railway baron Fröhlich von Feldau, von Wertheimer, Baron de Hirsch, von Lämel, the Rothschilds, the Eskeles, the Herzs, the Neuwalls and the Hönigsbergs. In Budapest the Wodianers, the Goldbergers, the Ullmanns, the Lánczys (Lazarsfelds), the Adlers, the Weisses and the Kornfelds (Aust, 2018; Wistrich, 1990; Rozenblit, 1993; Silber, 1992; McCagg, 1986; Frojmovics, Komoróczy, Pusztai, Strbik, 1999; Čapková, 2000; Macdonogh, 2012). Even though it lay in the periphery of the Habsburg Empire, Zagreb was no exception in this respect. The Alexander family, whose ancestors came from Burgenland and settled in Zagreb in the 1850s, left a strong mark on the social and economic life of Zagreb and Croatia for almost 100 years. They numbered almost 200 family members in seven generations, but today there is only one male descendent with the Alexander surname. He and his close relatives - the industrialist Samuel David's offspring - live scattered all 
over the world. The men of the older generation were traders, so their sons and grandsons were able to attend gymnasiums (grammar schools) and colleges and pursue successful careers in different fields. Thus, they became excellent doctors, proficient lawyers, engineers and gymnasium teachers, and one of them was even an artist. Most of them had an appreciation of beauty, and they cherished antiquities, music and fine literature. Some owned numerous houses, estates and factories, while others monopolised the Croatian economy for years (Mirnik, 1996b, p. 37).

So far, several papers have been published about the Alexander family. Some of them were written by Ivan Mirnik - a family descendant (Mirnik, 1995, pp. 96-127; Mirnik, 1996a, pp. 37-54; Mirnik, 1996b, pp. 37-52), while two were written by archivist Boris Zakošek (one individual paper and an addendum to Irina Alexander's memoirs) (Zakošek, 2002, pp. 121-153; Zakošek, 2003, pp. 333-352). However, in her monograph about Zagreb's economic elite in the second half of the 19th century, historian Iskra Iveljić also mentions the Alexander family (Iveljić, 2007, pp. 240242). Even though family members are mentioned in other works (Mirnik, 2012, pp. 395-417), a comprehensive monograph of the Alexander family is yet to be produced. Limited by its scope, this paper will not discuss all the members of the Alexander family; the focus will be on the life and work of two brothers: the nobleman Aleksander Alexander of Sesvete (1866-1929) and Samuel David Alexander (1862-1943). ${ }^{2}$

\section{The Jews of Zagreb}

Even though it is possible to speculate on the individual presence of Jews in Zagreb some 300 years ago, it is nonetheless unlikely that Jewish communities existed back then, since they can only be traced back to the end of the 18th century. Jews were first given permission to live in Zagreb in the 1780s. The first Jew to immigrate to Zagreb was Jakov/Jacob Stiegler in 1782 (Schwarz, 1939, p. 9; Švob, 2004, pp. 435, 495) or 1786, followed by Jacob Weiss in 1789 and Jacob Stern in 1789 (Goldstein, 1994, p. 298; Goldstein, 1998, p. 13; Dobrovšak, 2007, pp. 82-83). In 1806, 17 families formally established a joint Jewish community in two Zagreb districts Gradec and Kaptol. ${ }^{3}$ The Jews who came to Zagreb were all Ashkenazim

\footnotetext{
2 The author wishes to underline that most of the data in this paper was adopted from the works of one of the Alexander family members, Ivan Mirnik, grandson of Erich Alexander, who is still diligently researching his family history (Mirnik, 1995, pp. 96-127; Mirnik, 1996b, pp. 37-52).

3 At the end of the 11th century, King Ladislaus of Hungary established a Croatian Bishopric, known as Kaptol, adjacent to the fortified Slavic town, then called Gradec. After the Tartar
} 
from various parts of Central Europe. Most of the early arrivals migrated from Western Hungarian counties (today Burgenland), while others came from Moravia and Lower Austria, and some from Galicia. According to their occupation, most households' heads were merchants or petty traders, and some were artisans and communal functionaries. Just as the city of Zagreb experienced a period of rapid population growth in the late 19th and early 20th century (an increase from 29,218 inhabitants in 1880 to 74,703 in 1910 and 185,581 in 1931), so did the Jewish population (which doubled and redoubled from 1,285 in 1880 to 4,233 in 1910 and 8,702 in 1931). On the eve of the Second World War, the estimated number of Jewish residents in Zagreb was 9,467 (comprising 8,712 Ashkenazim-Neologs, 625 Sephardim and 130 Orthodox). Based on their occupation and income/wealth, the Jews of Zagreb were predominantly middle-class citizens. Approximately a third of the communal taxpayers in 1934 categorised themselves as merchants or commercial agents of various types, whereas almost an equal number were office clerks or some sort of paid employees. Slightly more than $8 \%$ were physicians, lawyers or engineers, and almost 3\% were considered industrialists, whereas another $3 \%$ apparently qualified as artisans. At that time Zagreb was therefore home to both the very rich and the very poor. The vast majority, however, fell between these two extremes and, by virtue of their income, their occupations and their education, Zagreb's Jews may thus be generally considered bourgeois. The Ashkenazim who came from elsewhere in the Habsburg Monarchy to live in Zagreb brought with them a variety of languages, mainly German and Hungarian. By 1880, according to the official census, $30 \%$ of the 13,488 Croatian Jews claimed Croatian as their mother tongue, whereas 56\% reported German and 12\% Hungarian. Later, the percentage of reported German speakers declined dramatically, but the number of Hungarian speakers remained constant. At the turn of the century, 54\% reported Croatian as their mother tongue and by 1910 the figure had reached $60 \%$. This statistic would imply that at the beginning of the 20th century, $83 \%$ of the Zagreb Jewish community had a working knowledge of the Croatian language. The trend towards linguistic acculturation continued during the inter-war period. In the 1931 Yugoslav census, 6,402 Zagreb Jews (75\%) reported Croato-Serbian as their mother tongue, 1,059 (12\%) acknowledged German and 653 (7\%) chose Hungarian, with the remaining $7 \%$ identifying themselves as speakers of other languages. Therefore, in the 20th century the Jews seemed to be trying

invasion in 1242, Gradec became a royal free town, noted for its fairs and handicrafts in addition to being an administrative centre. The two entities, the civil Gradec and the ecclesiastical Kaptol, continued to exist separately until 1850, when they officially merged with other nearby districts to form the City of Zagreb. 
hard to gain acceptance on the Zagreb scene, so there was a tendency to adopt Croatian names (in the Alexander family, personal names included Božidar, Vera, Ivo, Dragutin, etc.) as well as the Croatian language, so as not to be perceived as foreigners. The Jewish community of Zagreb was the best organised and established among all the Jewish communities in Croatia and Slavonia. Its Ashkenazi-Neolog component constituted the largest and wealthiest single Jewish community in the country. These Jews, whether merchants, white-collar workers or professionals, belonged predominantly to the middle class and, for the most part, were well educated, Westernised and secularised. By the 20th century most of them were at least bilingual, if not trilingual, speaking Croatian, German, and often Hungarian as well, whereas by culture and orientation they identified themselves more as Austro-Hungarian or Croatian than Yugoslav (for more about the Jews of Zagreb, see: Schwarz, 1903, pp. 89-104; Schwarz, 1939, pp. 7-100; Freidenreich, 1979, pp. 42-54; Goldstein, 1994, pp. 293-303; Goldstein, 1998, pp. 12-18; Švob, 2004, 1, pp. 33-55; Švob, 2010, pp. 72-113).

\section{"The Alexander Clan"4}

As mentioned above, the Alexander family's ancestors moved to Zagreb from Burgenland (Güssing/Nemetujvár; Vas County), coming from the estate of the Hungarian Batthyány noble family. In the second half of the 17th century, when Emperor Leopold I expelled the Jews from Lower Austria and later forbade them to establish their place of residence in free royal towns, the Batthyánys were among the major landowners who welcomed and accepted the Jews, allowing them to settle on their properties in the western part of Hungary, as they saw a potential economic advantage in their presence in local economic life. The first group of Jews came mainly from the Jewish communities of Nikolsburg and Uherský Brod. The Jews were accommodated and resettled by Esterházy in Sopron County, in the well-known Seven Communities of the Eisenstadt estate. In Rechnitz, the first large Jewish community with more than 30 families was established on the Batthyány estate in 1687. Their lives were governed by a letter of privilege received from the Batthyány family, which laid down the duties and rights of Jews and was used as a model for communities subsequently established in other settlements (Patai, 1996, pp. 188-193; Halper, 2012).

The precise date of the exiled Alexander family's migration from Styria to the Güssing area is unknown, though family tradition claims it happened before 1712 (Mirnik, 1995, p. 97). The names of the family's progenitors

4 Zdenko Vinski, son of Štefanija Vinski née Alexander, who said that the Alexanders were not a family but a large clan, used this term (Mirnik, 1995, p. 96). 
are unknown, and so are their lives in the 18th and early 19th century. The Alexander family can only be traced in Croatia from the mid-19th century, more precisely from 1851, when one of its members came to Zagreb, followed by the mother, three brothers and a nephew, leaving one brother behind in Güssing. The first generation was involved in commerce, while the next generation became successful businessmen, industrialists, bankers and philanthropists. The third generation branched into intellectual professions; its members enjoyed a more extravagant lifestyle, better education and a significantly more active social life until the Second World War (Iveljić, 2007, p. 242).

The great-grandparents of the Zagreb Alexanders were Samuel (Rechnitz, 1792 - Güssing, 1841) and Julija Yittel née Neumann (Güssing, 1803 Zagreb, 1882) (Julija Alexander, n.d.). ${ }^{5}$ Julija had five sons (Jacob, Josip/ Joseph, Jonas, Ljudevit/Ludwig, Aleksander/Šandor) and three daughters (Mimi - married name Sconheit, Netti - married name Mayer, and Rosalia who died as a child) (Mirnik, 1995, pp. 96-127; Mirnik 1996a, pp. 37-54; Mirnik 1996b, pp. 37-52).

Ljudevit/Ludwig (Güssing, 1835 - Zagreb, 1910), the fourth son in the line, first came to Zagreb in 1851 to attend commercial school and remained in the city for the rest of his life. In 1864 he married Leonora Weiss from Veszprém. After Leonora had given birth to two sons, Victor and Erich, she died in Vienna in 1868, just when, by virtue of the Diploma of the Magistracy of the Royal and Free Capital Zagreb, the merchant and houseowner Ljudevit was appointed a citizen of Zagreb (Mirnik, 1995, pp. 96-127; Mirnik 1996a, pp. 37-54; Mirnik 1996, pp. 37-52). According to the documents of the Zagreb City Archives, he acquired his citizenship in 1868 (Državni arhiv u Zagrebu [State Archives in Zagreb], Knjiga zavičajnika, No. 855, docum. 8406/1868). Ljudevit's first son was the lawyer Dr Viktor Alexander (Zagreb, 1865 - Zagreb, 1934), who quickly built a successful career and became a public prosecutor in Zagreb. The second son, Erich (Zagreb, 1868 - Zagreb, 1945), was a professor. He studied chemistry at the Technische Hochschule of Vienna, continuing his education in Zagreb and later in Gießen (at the Ludoviciana), where he obtained his doctor's degree. The widowed Ljudevit remarried two years later. He married Ida Weiss (?, 1848 - Zagreb, 1927) from Karlovac, and they had four children: the painter Artur Oskar (Zagreb, 1876 - Samobor, 1963), Gizela - married name Grünwald (Zagreb, 1873 - Samobor, 1952), Olga - married name Eisner (Zagreb, 1877 - Vienna, 1927), and Robert Milan/Emil (Zagreb,

Ivan Mirnik's research had originally noted that Julija's maiden name was Rubin, but the death certificate of her son Jakob and the marriage certificate of her son Ludwig list her maiden name as Neumann. 
1879 - Zagreb, 1941), a bank clerk and consul in Salzburg (Mirnik, 1995, pp. 96-127; Mirnik, 1996a, pp. 37-54; Mirnik 1996, pp. 37-52; Mirnik, 2012, pp. 395-417; Iveljić, 2007, pp. 240-242).

All the brothers came to Zagreb following their mother except Jacob/ Jakob (around Güssing, 1825 - Güssing, 1901), the eldest, who stayed in Güssing with his family and numerous relatives, and Josip (Güssing, 1830 - Zagreb, 1909), the second son, who was a trader in sewing essentials or "products for country people" and married Fanny Rozalija née Pollak (Güssing-Zagreb, 1914)(Mirnik, 1995,pp.96-127; Mirnik, 1996a,pp.37-54; Mirnik, 1996b, pp. 37-52; Iveljić, 2007, pp. 240-242). They had seven children: Samuel, Heinrich/Henrik, Rudolf, Rosa - married name Plachte, Aleksandar, Jakob and Olga (Josip Josef Aleksander, n.d.). ${ }^{6}$

The youngest son of Samuel and Julija was the trader Aleksander/Šandor (Güssing, 1837 - Zagreb, 1902). He had a small grocery and general store, a shop mainly selling "overseas and textile goods". His wife was Ivana née Hönigsberg (Zagreb, 1849 - Zagreb, 1922) from a prominent Zagreb family. They had five children: Robert (Zagreb, 1868 - Zagreb, 1908), Hermina married name Struempfler (Zagreb, 1870 - Zagreb, 1918), the engineer Levin (Zagreb, 1872 - Zagreb, 1925), Dr Oskar (Zagreb, 1873 - Vienna, 1929), and Zlata/Aurelija - married name Breyer (Zagreb, 1875 - Zagreb, 1942) (Mirnik, 1995, pp. 96-127; Mirnik, 1996a, pp. 37-54; Mirnik, 1996b, pp. 37-52; Iveljić, 2007, pp. 240-242).

The third son, Jonas Alexander (Güssing, 1832 - Zagreb, 1914) (“Aleksander, Jonas (Alexander)", n.d.), also moved to Zagreb. His wife was Rosa (Zagreb, 1842 - Zagreb, 1923), who came from a very old and influential Zagreb Jewish family, the Sterns (Schwarz, 1939, pp. 71-72). Jonas was a grain wholesaler, member of the City Council, councillor of commerce at the Zagreb Chamber of Commerce, member of the administration of the Croatian Cooperative Bank as well as vice-chairman of the Zagreb Savings and Investment Bank. He presided over the Chevra Kadisha for 35 years, and one of his famous sons later took over this function. He ran the company with his brothers and sons, keeping everything inside the family. He had two sons, S. D. (Samuel David) and Š. A. (Šandor/Aleksander), and daughters Gizela and Ilka. Jonas's elder daughter Gizela (Zagreb, 1867 - Zagreb, 1889) married her cousin Dr Mavro/Maurice Alexander (Güssing, 1855 - Zagreb, 1911), a well-known Zagreb physician. After she died, Mavro married her younger sister Ilka (Zagreb, 1860 - Jasenovac camp, 1942), who became a model mother to her stepdaughter (and niece) Stephanie/Štefanija - married name

6 In his 1996 text, Ivan Mirnik states that Josip Alexander had five children, while newer research suggests seven, of whom five were born in Güssing, while two were born in Zagreb (Mirnik, 1995, pp. 96-127; Mirnik, 1996, pp. 37-54; Mirnik, 1996, pp. 37-52). 
Weiss/Vinski (Zagreb, 1888 - Zagreb, 1942) (Mirnik, 1995, pp. 96-127; Mirnik, 1996a, pp. 37-54; Mirnik, 1996b, pp. 37-52).

Although members of the Alexander family could not be compared with, say, the Rothschilds of London or the Arnsteins of Vienna, they nevertheless belonged to the middle or upper class based on their wealth. Even though one family member achieved a noble title, they did not consider themselves nobility (McCagg, 1989). ${ }^{7}$ They never tried to live in the Zagreb Upper Town with the aristocracy but made a point of residing in the Lower Town (Mirnik, 1995, pp. 96-127; Mirnik, 1996a, pp. 37-54; Mirnik, 1996b, pp. 37-52; Iveljić, 2007, p. 242). Similarly to the situation in Vienna, the Alexander family was part of the social and economic elite. What the historian Wistrich writes in his book about Viennese Jews can also be applied to those in Zagreb, the only difference being that Zagreb's Jews became influential in the second rather than the first half of the 19th century. Wistrich states:

The social élite were clearly the bankers, suppliers, and monopoly leaseholders, next in prestige came the wholesale merchants in grain, wool, and hides, who also exported the finished products of textiles, silk, and dry-goods factories in and around Vienna to the province. They pioneered new methods of production and marketing as well as promoting the development of industry in the capital. This class of exceedingly rich financiers and merchants dominated Jewish society in early nineteenth-century Vienna. (Wistrich, 1990, p. 22)

Therefore, the next chapter of this paper focuses on the sons of Jonas, even though future historical research into the family's past could greatly benefit from additional investigation into the biographies of other family members.

\section{The Alexander Brothers: Renowned Entrepreneurs and Philanthropists}

This short family chronicle begins with an insight into Samuel (Sami) David's life and family, and then follows the life and family of his famous philanthropist brother Aleksander (Šandor).

Samuel (Sami) David Alexander (hereafter referred to as S.D.), known as Der Gescheite (The Smart One), was born in Zagreb on 13 July 1862 and died in Zagreb on 8 March 1943. After finishing elementary and high

C.f.: "Between the mid-18th century and the end of the Monarchy in 1918, the Habsburgs bestowed a rather large number of ranks and titles on their subjects. Of these, in Austria, 443 new noble ranks fell to 326 Jewish families, and an equivalent number went to some 350 Jewish families in Hungary" (McCagg, 1989, pp. 163-183). 
school in Zagreb, he enrolled in a business academy in Vienna. It was a logical step, since his father's business was in the cereal trade and the family had had a store in Zagreb since approximately 1860. In the years following Vienna, S.D. returned to Zagreb to work briefly for his father. However, in 1880 he moved to Sisak (an important river port, especially for cereal trade) to launch another store, thus expanding their family business through the acquisition of the local brewery and setting up of a malt factory. There he met his future wife. As was common in the business circles of the time, he wed Emma née Neumann (Varaždin, 1866 - Johannesburg, 1952), the daughter of his peer Wolf Neumann. They had three daughters and four sons: Vera (died as a child), Gizela - married name Roubeix (Sisak, 1893 - Nice, 1976), Mira (Sisak, 1902 - Pretoria, 1968), Ivo (Sisak, 1899 - Johannesburg, 1972), Božidar (Sisak, 1900 - La Tour de Peilz, 1976), Branko (Sisak, 1902 - Johannesburg, 1972), and Dragutin (Sisak, 1904 Johannesburg, 1968). All his children were born in Sisak.

When S.D. bought the Sisačka pivovara brewery in 1893, he also became actively engaged in Sisak society's development, being famous for his organisational skills (as a renowned organisational genius). Namely, he first supported the opening of the Sisak gymnasium school. Later he got involved in the local city council elections and was subsequently elected by the citizens as a council representative. Next to this prominent position, S.D. was a vice-president of the city's Savings and Support Society and the Savings and Loan Banking Society of the city and district of Sisak. However, when he bought shares in the Royal Privileged Zagreb Leather Factory at the beginning of the century, he became involved in its administration, which in 1912 introduced him to new opportunities and even greater projects. Namely, he bought the Zagreb Brewery Limited (today Zagreback $a$ pivovara) and a malt factory, which required his full attention, so eventually the family moved to Zagreb in $1915 .{ }^{8}$

Thus, S.D. moved back to Zagreb, where he could fully develop his organisational skills and realise a great deal of his potential. He took part in the activities of the trading section of the Chamber of Commerce in Zagreb, was involved in establishing the Croatian-Slavonian Industrialists' Association, and was active in the Industrialists' Association of the Sava Banovina next to the Industrial Corporation Centre in Belgrade. He also worked with

\footnotetext{
8 At first the beer was not very popular, so S.D. invited experts from Bohemia to find out why the beer was not good. They determined that the water quality was poor, so they suggested some improvements, and Zagreb's beer became excellent. The Alexander family ran the Zagreb Brewery until 1940, when they withdrew from the business because the Banovina of Croatia's Government issued a regulation prohibiting Jews from getting involved in the production and sale of food (Mirnik, 1995, pp. 96-127; Mirnik, 1996, pp. 37-54; Mirnik, 1996b, pp. 37-52; Kolar, 2002, pp. 33-40; Kolar-Dimitrijević, 1992, pp. 149-168; Despot, 1983, pp. 71-72).
} 
other partners in the Croatian Discount Bank. One of his numerous plans was to build and establish the First Croatian Oil Factory as well as the coal company Mirna Ltd. However, S.D. soon became the owner of several companies in Zagreb: the ceramics companies Titanit Ltd and Danica Ltd, the construction company Zagorka Ltd, and also some important factories in Podsused (e.g. Portland Cement Croatia Ltd). Next to this, S.D. participated in the establishment of the Zagreb Stock Exchange in 1907 and Zagreb Zbor (today known as the Zagreb Fair) in 1908/9. The many prominent positions he occupied also included the presidency of the Industrialists' Association in 1919 and board membership of the Chamber of Commerce in Zagreb. Under his leadership, industrial entrepreneurs in Croatia and Slavonia were united in the Industrialists' Association in their effort to gain a more favourable position on the Austro-Hungarian market for manufactured goods and to participate as equals in economic policy-making (Mirnik, 1995, pp. 96-127; Mirnik, 1996a, pp. 37-54; Mirnik, 1996b, pp. 37-52).

It is therefore no surprise that, over time, S.D. became the owner of several residential buildings in Zagreb, and was very much present in the life of the Jewish community. He was an active member of the Jewish community in Zagreb (mostly pro-Zionist) even though he strongly believed in assimilation and was a member of the Association of Jewish Assimilates and Anti-Zionists in Croatia - Narodni Rad. A philanthropist like his brother Aleksander, S.D. supported many charitable activities. However, during the Second World War and the Ustasha regime in the Independent State of Croatia, his and his family's circumstances changed. S.D. and his wife became recipients of charity as they found much-needed refuge in those times of persecution ${ }^{9}$ at Dr Đuro Vranešićs sanatorium in Klaićeva Street, Zagreb, where S.D. subsequently died of natural causes at the age of 80 in $1943 .{ }^{10}$ The lives of his offspring followed various different paths in and outside Croatia.

S.D.'s first son, Ivo, was an entrepreneur. He was drafted into the army in the First World War, and upon his return he was the manager of the Zagreb Brewery. Ivo was also mobilised as an officer of the Yugoslav Army on the eve of the Second World War. However, he was captured in Niš (Serbia) by the Germans and deported to the Osnabrück Camp. Ivo survived the horrors of the Second World War and returned to Zagreb, only to move to South Africa in 1948, taking his mother and remaining brothers with him (Mirnik, 1995, pp. 96-127; Mirnik, 1996a, pp. 37-54; Mirnik, 1996b, pp. 37-52).

\footnotetext{
9 Together with 80 other members of Zagreb's Jewish community.

10 To save themselves, the remaining members of S.D.s family fled under various circumstances to countries all over the world (Mirnik, 1995, pp. 96-127; Mirnik, 1996a, pp. 37-54; Mirnik, 1996b, pp. 37-52).
} 
The second son, the lawyer Božidar, married the famous Russian writer and translator Irina Kunjina (Sankt Petersburg, 1900 - Geneva, 2002), called Iročka. Irina was a living cultural institution in the 1920s and 1930s in Zagreb and a gifted author, in whose parlour one could meet numerous painters, sculptors and writers, the most prominent among them undoubtedly being Croatian writer Miroslav Krleža (Zagreb, 1893 Zagreb, 1981) (Mirnik, 1995, pp. 96-127; Mirnik, 1996a, pp. 37-54; Mirnik, 1996b, pp. 37-52; Žinić, 2001, pp. 119-124; Zakošek, 2003, pp. 333-352; Lukšić, 1999, pp. 33-46).

The third son, Branko, married Maja/Marija Unger (Vienna, 1905 London, 1990), the favourite adopted child of a noble and wealthy Zagreb Jewish family, the Deutsch-Maceljskis (Albert and Matilda). ${ }^{11}$ Branko and Maja had two daughters and a son. Together with his brother Dragutin, he co-owned three family companies: the coal company Mirna Ltd., the First Croatian Oil Factory, and the Zagreb Brewery Ltd. Finally, S.D.'s fourth son, Dragutin Toma, a mining engineer, married the Estonian Helmi Nurk (1900-1996). They had two daughters: Ksenija or Kisa and Nina (Mirnik, 1995, pp. 96-127; Mirnik, 1996a, pp. 37-54; Mirnik, 1996b, pp. 37-52).

One of S.D.'s daughters, the twin sister of Božidar, Mira, was married to Rotary Club governor and lawyer Jozo Poduje (1892-1979). Her second husband was Dr Milutin Juzbašić, a lawyer and landowner from Požega and a shareholder of the Zagreb Brewery Ltd., while her third husband in South Africa was a Polish count named Starszensky. She converted to Catholicism in 1927 (Zakošek, 2003, p. 337). S.D.'s second daughter, Giza, married a Frenchman called Maurice Roubeix who owned a villa in Nice, where they moved from Zagreb before the German occupation (Mirnik, 1995, pp. 96-127; Mirnik, 1996a, pp. 37-54; Mirnik, 1996b, pp. 37-52).

S.D.'s more famous younger brother Aleksander (Šandor), also known as Alexander Sesvetski (of Sesvete), Š.A. or Der Berühmte (The Notable One), was born in Zagreb on 5 April 1866 and died in Belgrade in the night of 17/18 December 1929 while attending the Royal Guards' Ball. He was undoubtedly the best-known member of the Alexander family. Unlike his older brother S.D., after finishing high school Aleksander stayed in Zagreb and became a partner in his father's business. He married Carolina (Dragojla) née Ebenspanger (Varaždin, 1873 - Zagreb, 1925), who was from the Varaždin Jewish family (Mirnik, 1995, pp. 96-127; Mirnik, 1996a, pp. 37-54; Mirnik, 1996b, pp. 37-52), and they had only one child,

11 The brothers Benko, Vilim and Albert launched the family firm Sons of Filip Deutsch, dealing in wood and the forest products industry, in 1894. In 1910 Albert Deutsch and his family gained the status of Hungarian-Croatian nobility and added "od Macelja" to their surname. 
daughter Zora (Zagreb, 1895 - Auschwitz, 1944). ${ }^{12}$ His professional and public magnitude became obvious very soon, when he proved himself to be an excellent economic expert and a gracious philanthropist.

Namely, as a businessman Aleksander was a major stockholder of the First Croatian Machine Factory and the Iron Foundry in Zagreb as well as some other companies. In his long business career, Aleksander also encouraged tourism development in Croatia and was a major shareholder of the Schlesinger Palace (now the Palace Hotel) in Zagreb (Mirnik, 1995, pp. 96-127; Mirnik, 1996a, pp. 37-54; Mirnik, 1996b, pp. 37-52). Being an economic expert publishing papers in professional periodicals of the time (i.e. Bankarstvo journal) and an accomplished businessman, Aleksander was elected as a member of various important business, public and financial institution boards. He was a member of the boards of numerous trade companies, manufacturing businesses and banks (i.e. the Bank of Trade and Industry in Zagreb, the Croatian Trust Bank, the First Croatian Machine Factory, the Iron Foundry in Zagreb, the Croatian Credit Bank, and the Trading Bank of Zagreb). He played an important role in various economic organisations and associations, most notably in positions he held in the Chamber of Commerce, Trgovački dom (approx. Traders' Centre) and the Association of Croatian and Slavonian Merchants. Moreover, Aleksander also held some important positions in the Merkur Croatian Trading Association from 1885, working intensely within the association to improve technical colleges. He was first its vice-president, then from 1892 its president, becoming lifetime president in 1910. All these duties and his position in various companies as well as cultural and other associations enabled him to be directly or indirectly involved in various humanitarian fundraising activities in many different ways.

Before the First World War, as an acting representative of the City Council in Zagreb (1905-1910) and official advisor to Franz Joseph I of Austria (1909), Aleksander participated in numerous charitable activities, becoming a true philanthropist in Croatia. As early as 1908, he founded the Society to Feed Zagreb's Primary School Poor Youth, and he contributed greatly to the Croatian Academic Society for the Support of the Poor and

\footnotetext{
12 Zora's first husband was the early deceased Bogdan Ausch (? 1885 - Zagreb, 1915); her second husband was the Croatian Jewish industrialist and merchant, millionaire Dr Artur Marić, born Mayer (Zagreb, 1889 - Petrinja, 1941). In 1941 Zora Marić fled Zagreb and spent a long time in the Italian camp in Kraljevica, but the Germans took her into custody and killed her after Mussolini's defeat. Her second husband, Dr Artur Marić, did not die from natural causes either; he was robbed and killed in Petrinja just as he was about to reach safety. Zora had two daughters, Božena Ausch-Marić - married name Glumac (Zagreb, 1915 - Zagreb, 1993) from her first marriage, and Mira Marić - married name Milivojević, later Rašić, from her second marriage (Mirnik, 1995, pp. 96-127; Mirnik, 1996a, pp. 37-54; Mirnik, 1996b, pp. 37-52).
} 
Sick Academic Citizens. During the First World War he founded and financed the Merkur Advanced Payment Bank for War-Handicapped People (Mirnik, 1995, pp. 96-127; Mirnik, 1996a, pp. 37-54; Mirnik, 1996b, pp. 37-52) which, among other things, advocated vocational education development, and was an active member of the Humanitarian Society (Mirnik, 1995, pp. 96-127; Mirnik, 1996a, pp. 37-54; Mirnik, 1996b, pp. 37-52; Kolar-Dimitrijević, 1989, p. 39). At the same time, he and his older brother Samuel David organised and covered most of the expenses made by the Unemployment and Disabled Employees Support Committee of the Commercial and Industrial Sector and Financial Institutions. Aleksander's greatest philanthropic contribution was the soup kitchen he established through his welfare organisation Prehrana (Nourishment), in the Art Pavilion's basement, serving meals to poor citizens and the families of frontline soldiers. Prehrana remained active until 1941, feeding hungry poor people. The central academic canteen for students was also established as part of the same foundation (Mayer, 1939, p. 3; Mirnik, 1995, pp. 96-127; Mirnik, 1996a, pp. 37-54; Mirnik, 1996b, pp. 37-52; Kolar, 2012, p. 87). Furthermore, Aleksander was a member of the National Labour Association of Jewish Assimilates and Anti-Zionists in Croatia. Much like his brother Alexander, S.D. gave almost everything he earned to charity, while their wives, sisters, daughters and other female relatives - such as Ilka and Giza Alexander - were also active in charity work. Since Aleksander was the president (1913-1928) of the Chevra Kadisha Jewish funeral home, he was able to provide charity in this respect as well (Mirnik, 1995, pp. 96-127; Mirnik, 1996a, pp. 37-54; Mirnik, 1996b, pp. 37-52). In 1917 Aleksander was awarded the Austro-Hungarian War Cross for Civil Merits 2nd Class for his charity activities during the First World War. He was raised to nobility when Austrian Emperor and Croatian-Hungarian King Karl I awarded him the title of Sesvete on 13 August 1918 in acknowledgment of his generous donation of one million Austrian gold crowns as a war loan (Mirnik, 1995, pp. 96-127; Mirnik, 1996a, pp. 37-54; Mirnik, 1996b, pp. 37-52). His charity work and donations, which made him a true philanthropist, continued after the war until his death and beyond, through the Alimentation Fund (Mayer, 1939, p. 20) he had helped establish (KolarDimitrijević, 1998, p. 39; Kolar, 2012, p. 87).

\section{Conclusion}

Even though the progenitors of this family were of the Jewish faith, and the two brothers described here married Jewish women, most members of the family converted to Catholicism after the end of the First World 
War, while one member, the painter Oskar Artur, was a member of the Evangelical Church. When they arrived in Zagreb in the mid-19th century, they were petty traders by profession, but already the second generation, who lived in the late 19th century, and especially after the First World War, became very distinguished and wealthy industrialists and bankers. In addition to their economic activity, they were active within the Jewish community, and were also members of almost all the charities and cultural and academic institutions of Zagreb. By establishing marriage and business links with distinguished Zagreb families of various faiths (Stern, Marić/ Mayer, Deutsch-Maceljski), they became known as one of the city's most distinguished families. Today the third-, fourth- and fifth-generation descendants of this family mostly live dispersed throughout the world, with only few living in Zagreb. Apart from these few descendants, the only testament to the family in Zagreb are the stairs leading from Rokov Park to Dežmanov Passage, which are named after Aleksander/Šandor. A bust of Šandor used to stand in front of his house before the new communist authorities removed it along with the accompanying plaque. It might appear that the Alexander family, even though it was one of the most distinguished in the city and its activities were reported in the newspapers daily, today is only present in academic papers such as this one. Nonetheless, in this way the Alexander family chronicle has found its place in Croatian historiography, just like this Jewish family left an unprecedented and everlasting mark on Zagreb's life and economy at the turn of the 19th and 20th centuries.

\section{References}

Aleksander, Jonas (Alexander). (n.d.). In Židovski biografski leksikon. Retrieved November 21, 2019, from https://zbl.lzmk.hr/?p=2977

Aust, C. (2018). The Jewish economic elite: Making modern Europe. Indiana University Press. https://doi.org/10.2307/j.ctt2204p4w

Čapková, K. (2000). Jewish elites in the 19th and 20th centuries, The B'nai B'rith Order in Central Europe. Judaicae Bohemiae, 36(1), 119-142.

Despot, M. (1983). Aleksander, Samuel D. (Alexander). In N. Kolumbić (Ed.), Hrvatski biografski leksikon (pp. 71-72). Jugoslavenski leksikografski zavod.

Dobrovšak, L. (2007). Razvoj židovskih zajednica u Kraljevini Hrvatskoj i Slavoniji (1783-1873) [Unpublished doctoral dissertation]. Sveučilište u Zagrebu.

Freidenreich, H. P. (1979). The Jews of Yugoslavia: A quest for community. The Jewish Publication Society of America.

Frojmovics, K., Komoróczy, G., Pusztai, V., \& Strbik, A. (1999). Jewish Budapest, monuments, rites, history. CEU Press. 
Goldstein, I. (1994). Židovi na Gradecu od 14. stoljeća do 1848. godine. In I. Kampuš (Ed.), Zagrebački Gradec 1242.-1850. (pp. 293-303). Grad Zagreb.

Goldstein, I. (1998). Zagrebačka židovska općina od osnutka do 1941. In O. Kraus (Ed.), Dva stoljeća povijesti i kulture Židova u Zagrebu i Hrvatskoj (pp. 12-18). Židovska općina Zagreb.

Halper, P. (2012). „Die jüdische Gemeinde in Güssing.” Vertreibungen, “Arisierungen” und Rückstellungen [Master's thesis, Universität Wien]. http://othes.univie.ac. at/25127/1/2012-12-31_0609336.pdf

Iveljić, I. (2007). Očevi i sinovi: Privredna elita Zagreba u drugoj polovici 19. stoljeća. Leykam International.

Josip Josef Aleksander. (n.d.). Geni. Retrieved December 6, 2019, from https://www. geni.com/people/Josip-Aleksander/6000000049213371881

Julija Alexander. (n.d.). Geni. Retrieved December 2, 2019, from https://www.geni. com/people/Julija-Alexander/6000000049211371788

Kolar, M. (2002). Zagrebačka pivovara do 1945. Hrvatska revija, 2(3), 33-40.

Kolar, M. (2012). Prehrana u Hrvatskoj tijekom 1918. godine. In Ž. Holjevac (Ed.), 1918. u hrvatskoj povijesti (pp. 73-96). Matica Hrvatska.

Kolar-Dimitrijević, M. (1992). Presjek kroz rad Zagrebačke pivovare d.d. do 1945. godine. Časopis za suvremenu povijest, 24(2), 149-168.

Kolar-Dimitrijević, M. (1998). Društvo čovječnosti 1846-1946. Židovska općina Zagreb.

Lukšić, I. (1999). Ruski emigranti u Hrvatskoj između dva svjetska rata. In I. Lukšić, Hrvatska -Rusija: Kulturno-povijesne veze (pp. 33-46). Društvo hrvatskih književnika; Biblioteka Relations.

Macdonogh, G. (2012). In search of Vienna's vanished elite. Standpoint. https:// standpointmag.co.uk/issues/march-2012/features-march-12-in-search-ofviennas-vanished-jewish-elite-giles-macdonogh-rinstrasse-zwieback-family/

Mayer, V. (1939). Dobrotvorno društvo "Prehrana" 1914. -1939. Union grafički nakladni zavod.

McCagg, W. O., Jr. (1986). Jewish nobles and geniuses in modern Hungary. Columbia University Press.

McCagg, W. O., Jr. (1989). Austria's Jewish nobles, 1740-1918. The Leo Baeck Institute Year Book, 34(1), 163-183. https://doi.org/10.1093/leobaeck/34.1.163

Mirnik, I. (1995). Obitelj Alexander ili kratka kronika izbrisanog vremena. Radovi Zavoda za hrvatsku povijest, 28, 96-127.

Mirnik, I. (1996a). The Alexanders, or the history of a Zagreb Family in past perfect. In J. Domaš Nalbantić (Ed.), Family (pp. 37-52). Zagreb Jewish Community.

Mirnik, I. (1996b). Obitelj Alexander ili povijest jedne zagrebačke obitelji u pluskvamperfektu. In J. Domaš Nalbantić (Ed.), Obitelj (pp. 37-54). Kulturno društvo Miroslav Šalom Freiberger.

Mirnik, I. (2012). Referat dr. Viktora Alexandera caru Carlu. In Ž. Holjevac (Ed.), 1918. u hrvatskoj povijesti (pp. 395-417). Matica Hrvatska.

Patai, R. (1996). The Jews of Hungary, history, culture, psychology. Wayne State University Press. 
Rozenblit, L. M. (1993). The Jews of Vienna, 1867-1914: Assimilation and identity. State University of New York.

Schwarz, G. (1903). Prilozi k povijesti Židova u Hrvatskoj: Iz starine zagrebačke općine 1806-1845. Vjesnik kr. Hrvatsko-slavonsko-dalmatinskog Zemaljskog arkiva, 1903, 89-104.

Schwarz, G. (1939). Povijest zagrebačke židovske općine od osnutka do 50-tih godina 19. vijeka. Gaj.

Silber, K. M. (Ed.). (1992). Jews in the Hungarian economy 1760-1945: Studies dedicated to Moshe Carmilly-Weinberger in his eightieth birthday. The Magnes Press, The Hebrew University.

Švob, M. (2004). Židovi u Hrvatskoj - židovske zajednice / Jews in Croatia-Jewish communities (Vol. 1). K. D. Miroslav Šalom Freiberger; Židovska općina Zagreb.

Švob, M. (2010). Židovska populacija u Hrvatskoj i Zagrebu. Židovska općina Zagreb; Istraživački i dokumentacijski centar CENDO.

Wistrich, S. R. (1990). The Jews of Vienna in the age of Franz Joseph. Oxford University Press.

Zakošek, B. (2002). Obitelj Aleksander. Vjesnik Državnog arhiva u Rijeci, 42-43, 121-153.

Zakošek, B. (2003). Irina u obitelji Aleksander, Irina Aleksander. In I. Lukšić (Ed.), Svi životi jedne ljubavi (pp. 333-352). Hrvatsko filološko društvo; Naklada Jesenski i Turk.

Žinić, S. (2001). Radovi ruskih emigranata u Hrvatskoj. Književna smotra, 33(1), 119-124.

\section{Kronika obitelji Alexander}

U tekstu je prikazana povijest zagrebačke židovske obitelji Alexander (Aleksander) koja je nešto manje od stotinu godina igrala važnu ulogu u gospodarskom, kulturnom i društvenom životu Zagreba i Hrvatske. U trenutku dolaska u Zagreb, svi su bili židovske vjeroispovijesti, da bi do 1941. godine veći dio obitelji prešao na katoličanstvo, a jedan među njima bio je i evangelik. Obitelj se sredinom 19. stoljeća doselila iz Gradišća (Burgenlanda) u Zagreb. Po dolasku u Zagreb, otvorili su trgovine, no kako su bili skloni neumornom radu, vrlo brzo su napredovali u hrvatskom društvu, te su pred kraj 19. stoljeća postali jedna od uglednijih i imućnijih obitelji u Zagrebu i Hrvatskoj, a i šire. U drugoj generaciji, članovi ove obitelji istaknuli su se kao vrsni liječnici, pravnici, inženjeri, umjetnici, profesori i poduzetnici. Po dolasku u Zagreb, sklapali su brakove sa najstarijim 
i vrlo utjecajnim zagrebačkim židovskim i katoličkim obiteljima, družili se s plemstvom te tako sklapali unosna poznanstva i veze koje su im omogućile ubrzani uspon u društvu. Bili su kozmopoliti, s jednom nogom u Zagrebu, s drugom u Beču, a ni Budimpešta im nije bila strana. Među njima, svojim sposobnostima isticala su se dvojica braće Aleksander/Šandor (1866.1929.) i Samuel David (1862.-1943.). Bili su ugledni industrijalci i osnivači zagrebačke pivovare, tvornice slada, uljare, cementare i drugih industrijskih postrojenja u Zagrebu. Bili su u odboru nekoliko zagrebačkih banaka i osnivači su nekoliko industrijskih udruženja. Posebno su se istaknuli za vrijeme Prvoga svjetskoga rata, te je zbog zasluga na humanitarnom polju, Aleksander dobio ugarsko plemstvo. Niti ulazak u Kraljevinu SHS/ Jugoslaviju nije pogoršao njihovu poziciju, dapače, nastavili su i dalje uspješno poslovati. Kada je počeo Drugi svjetski rat, veći dio obitelji iselio se iz Nezavisne Države Hrvatske, te je tek nekolicina stradala u Holokaustu. Danas potomci ove velike obitelji žive u Izraelu, Sjedinjenim Američkim Državama, Italiji, Zagrebu, a o njihovom postojanju svjedoče jedino stube na Tuškancu koje nose ime Šandora pl. Alexandera Sesvetskog.

Ključne riječi: Obitelj Alexander, Židovi, poduzetnici, Zagreb.

\section{Kronika rodziny Alexander}

W tekście zaprezentowana jest historia rodziny Alexander (Aleksander), żydowskiej rodziny z Zagrzebia, która prawie przez sto lat odgrywała ważną rolę w gospodarczym, kulturalnym i społecznym życiu miasta oraz całej Chorwacji. W czasie osiedlenia się w Zagrzebiu wszyscy członkowie rodziny byli wyznawcami judaizmu, jednak do 1941 roku większość z nich przeszła na katolicyzm, a jeden z nich dołączył do wyznawców kościoła ewangelickiego. Rodzina do Zagrzebia przybyła w połowie XIX wieku z terenu Gradišće (Burgenland). Po osiedleniu się zaczęła działać w handlu, a ponieważ członkowie rodziny byli niezwykle pracowici, już przed końcem XIX wieku rodzina stała się jedną $\mathrm{z}$ najbardziej szanowanych i majętnych, zarówno w Zagrzebiu, jak i w Chorwacji, a nawet poza nią. Już w drugim pokoleniu członkowie rodziny wyróżniali się jako znakomici lekarze, prawnicy, inżynierowie, artyści, profesorowie i przedsiębiorcy. W Zagrzebiu zawierali małżeństwa z członkami wpływowych rodzin, zarówno żydowskich, jak i katolickich, pozostawali w stosunkach towarzyskich z lokalną elitą i w ten sposób zyskali wysoki status w otoczeniu. Byli kosmopolitami: życie dzielili między Zagrzeb i Wiedeń, a i Budapeszt nie był im obcy. Wśród nich swoimi talentami wyróżniali się bracia Aleksander/Šandor (1866-1929) 
i Samuel David (1862-1943). Byli szanowanymi przemysłowcami: założyli zagrzebski browar, fabrykę słodu, olejarnię, cementownię i inne obiekty przemysłowe $\mathrm{w}$ Zagrzebiu. Zasiadali $\mathrm{w}$ zarządach kilku zagrzebskich banków, założyli także kilka towarzystw przemysłowych. Wyróżnili się w czasie I wojny światowej, a Aleksander otrzymał węgierski tytuł szlachecki za swoją działalność humanitarną. Okres Królestwa SHS/Jugosławii również nie zagroził ich pozycji, co więcej - nadal z powodzeniem pracowali i działali. Po wybuchu II wojny światowej większość członków rodziny opuściła Niezależne Państwo Chorwackie, kilkoro z nich zginęło w czasie Holokaustu. Obecnie potomkowie tej wielkiej rodziny mieszkają w Izraelu, Stanach Zjednoczonych Ameryki, we Włoszech oraz w Zagrzebiu, a o ich obecności w historii miasta świadczą schody na Tuškanacu, które noszą imię Šandora Alexandra Sesveckiego.

Słowa kluczowe: rodzina Alexander, Żydzi, przedsiębiorcy, Zagrzeb.

Przekład z języka chorwackiego Aleksandra Twardowska

\section{Note}

Ljiljana Dobrovšak, Institute of Social Sciences Ivo Pilar, Zagreb.

Ljiljana.Dobrovsak@pilar.hr

Ivana Žebec Šilj, Institute of Social Sciences Ivo Pilar, Zagreb.

Ivana.Zebec@pilar.hr

The preparation of this article was self-funded by the authors.

All authors participated equally in the concept of the study and drafting the manuscript.

No competing interests have been declared.

\section{Publication History}

Received: 2019-12-13; Accepted: 2020-12-04; Published: 2020-12-31 